\title{
ECONOMIC VIABILITY OF A MINERAL WATER INDUSTRY: A RISK ANALYSIS STUDY
}

Artur Angelo Alcântara de Assis ' Carlos Otávio Petter ' Júlio César de Souza ${ }^{2}$

\begin{abstract}
In order to understand and estimate the risks of failure associated with investing in a mineral water project, it is essential to carry out some types of analysis, such as: (i) economic viability; (ii) risk; (iii) sensitivity and; (iv) scenarios. This study presents a risk analysis approach developed from Software Risk simulator for a mineral water industry in the state of Piauí in the Brazilian Northeast. The data used were obtained through the Economic Utilization Plan (EUP) for the year 2015. It should be noted that the analysis techniques used for the construction of the risk analysis were: tornado analysis, sensitivity analysis, Monte Carlo simulation and analysis of scenario. The realization of this study made it possible to identify the most impacting variables in the cash flow in this mineral water enterprise. Finally, all these analyses are essential to evaluate the risks of failure, investments and economic viability of a mineral water undertaking, being fundamental for the planning and decision making the execution of all the steps carried out in this study.
\end{abstract}

Keywords: Risk analysis; Mineral water; Sensitivity analysis; Economic viability.

\section{VIABILIDADE ECONÔMICA DE UMA INDÚSTRIA DE ÁGUA MINERAL: UM ESTUDO DE ANÁLISE DE RISCO}

\section{Resumo}

A fim de compreender e estimar os riscos de insucesso associados ao investimento em um projeto de mineração de água mineral, é fundamental realizar alguns tipos de análises, tais como: (i) de viabilidade econômica; (ii) de risco; (iii) de sensibilidade e; (iv) de cenários. Este estudo apresenta uma abordagem de análise de risco desenvolvida a partir do Software Risk Simulator para uma indústria de água mineral do estado do Piauí no nordeste brasileiro. Os dados utilizados foram obtidos através do Plano de Aproveitamento Econômico (PAE) referente ao ano 20I5. Destaca-se que as técnicas de análises utilizadas para a construção da análise de risco foram: análise Tornado, análise de sensibilidade, simulação de Monte Carlo e análise de cenário. A realização deste estudo possibilitou identificar as variáveis mais impactantes no fluxo de caixa nesse empreendimento de água mineral. Por fim, todas essas análises são essenciais para avaliar os riscos de insucesso, os investimentos e a viabilidade econômico-financeiros de um empreendimento de água mineral, sendo fundamental para o planejamento e tomada de decisão a execução de todas as etapas realizadas neste estudo.

Palavras-chave: Análise de risco; Água mineral; Análise de sensibilidade; Viabilidade econômica.

\section{INTRODUCTION}

Water is a natural resource of incalculable value, considered primordial for the existence and maintenance of living beings. Besides being seen as a source of life, the water is a strategic resource for economic development [ 1$]$. The demand for the consumption of water free from contamination coupled with the concern with water quality has intensified this segment of the market, especially the mineral water.

Given this scenario, it is fundamental that companies that invest in a mineral good carry out some types of analysis, such as: (i) economic viability; (ii) risk; (iii) sensitivity and; (iv) scenarios in order to understand and estimate what

'Programa de Pós-graduação em Engenharia de Minas - PPGE3M, Universidade Federal do Rio Grande do Sul - UFRGS, Porto Alegre, RS, Brasil. E-mail: arturaaa@hotmail.com

2Programa de Pós-graduação em Engenharia de Minas, Universidade Federal de Pernambuco - UFPE, Recife, PE, Brasil. 
investments are required and the risks for undertaking a mineral water exploitation project.

Such analyses can be carried out using specific software, such as the Risk simulator, a computational tool that allows the forecasting, optimization and simulation of Monte Carlo, developed by the North American company Real Options Valuation. This software quickly generates a probability histogram, graphic tornado, sensitivity graph and analyses of scenarios.

Thus, the objective of this article is to present the risk analysis generated by Software Risk simulator in a mineral water industry in the state of Piauí. This industry was selected for the study due to the availability of the financial data necessary to carry out the risk analysis.

\section{MATERIALS AND METHOD}

In this section, the materials and methods adopted to carry out this study are presented. The financial data of a mineral water industry located in the state of Piauí were used in the research. These data refer to the year 2015 and were extracted from the Plano de Avaliação Econômica (Economic Utilization Plan) delivered to the Agência Nacional de Mineração (National Mining Agency). This industry was chosen because it provided all the financial data needed to carry out the risk analysis.

The chosen industry produces bottles of 20 and 10 liters, bottles of $1.500,500$ and $350 \mathrm{ml}$ and cups of $200 \mathrm{ml}$. The initial investment was $R \$ 2,053,000.00$, the annual gross revenue of $R \$ 2,736,976.62$ and the annual operating cost of $R \$ 1,587,251.09$. The income tax rate used was $15 \%$, financial compensation for the exploitation of mineral resources (CFEM) of $1 \%$, tax on circulation of goods and services (ICMS) of $18 \%$, Social Integration Programs (PIS) and the contribution to social security financing (COFINS) of $3.65 \%$, social contribution on net income (CSLL) of $9 \%$ and the minimum attractiveness rate (TMA) was $13 \%$.

It should be noted that the reference value chosen for the TMA was based on the rate of the special settlement and custody system (Selic) for April 2018 of $6.5 \%$. Due to the high risk nature of investment in a mining company, it was decided to use twice the Selic rate (I3\%) for a closer calculation.

From these data, the cash flow in excel spreadsheet was calculated and the net present value (NPV) was calculated. NPV is the present value of discounted future receipts at the interest rate, minus the present value of operating costs and the initial investment. The definition of NPV is that of an algebraic sum of cash flows obtained in a period of time " $\mathrm{t}$ " discounted for the present instant, at an interest rate " $i$ " [2].

The risk analysis software used in this research was the risk simulator, due to the researchers having unrestricted access to this tool, which enabled the development of the study. However, it is important to note that there are other systems that perform such activity. The risk simulator works with Excel as a supplement to perform Monte Carlo prediction, optimization and simulation analyses. It should be emphasized that the analysis techniques used were: tornado analysis, sensitivity analysis, Monte Carlo simulation and scenario analysis, which will be explained below.

The tornado analysis was chosen to identify which variables have the most impact on the cash flow and to select among these, the 5 most impacting variables in the cash flow result. It is worth mentioning that this analysis was chosen to the detriment of other existing ones because it is able to capture the static impacts of each variable in the model result. In this way, the tool automatically modifies each variable by a predefined value by the user, captures the fluctuation in the model forecast or the final result, and lists the resulting perturbations sorted in descending order of relevance. Thus, the tornado graphic identifies which variables most affect the economic outcomes that must be modeled for risk simulation.

After selecting the 5 most impacting variables, the probability of occurrence of results (probability distribution of NPV) was simulated based on those 5 variables. This step was performed through the simulation of Monte Carlo, parameter used by the risk simulator. Simulation techniques are relevant tools for predicting and minimizing risks, as well as understanding the uncertainties of a project [3]. In this respect, each project requires the application of the technique that best suits its needs, since there are different tools. One of these is the Monte Carlo simulation, which simulates, through the generation of random numbers, many project parameters with statistically modeled characteristics.

A simulation calculates numerous scenarios of a model by repeatedly selecting values from a predefined probability distribution by the user for the economic variables of the cash flow and uses these values in the model for calculating the economic decision criterion, in the case the NPV. All of these scenarios produce associated results in a model, where each scenario can have a forecast. Predictions are events (usually with formulas or functions) that you define as important results of the model. In general, these are events such as net income or gross expenses.

The Monte Carlo method can be widely used in project evaluation, where the risks involved can be expressed in a simple and easy-to-read format, where simulations aid decision making [4].

Then, the sensitivity analysis was performed, applying dynamic disturbances created after the simulation was executed. Sensitivity graphics result from dynamic perturbations where several assumptions are simultaneously destabilized and their interactions in the model and correlations between variables are captured in the fluctuations of the results. Sensitivity graphics identify the impact on results when multiple variables that interact are simulated in the model.

The scenario analysis was performed only for the price variable of the $20 \mathrm{~L}$ bottle because it is the most impacting on the cash flow results. The scenario analysis tool allows you to run several possibilities by changing one 
or two input parameters of the cash flow to determine the result of a variable. In this step you can define the initial and final values to be tested, plus the size of the increment or the number of steps that must be performed between the initial and final values. The result is a scenario analysis chart.

\section{RESULTS AND DISCUSSION}

\section{I Cash Flow}

Based on the financial data collected in the Plano de Aproveitamento Econômico (Economic Utilization Plan) delivered to the Agência Nacional de Mineração (National Mining Agency) in the year 2015, the cash flow of the mineral water enterprise was developed over period of 10 years [5]. The net income found was $R \$ 576,310.93$ per year, from year I to year 10. The NPV was R\$ I,074,203.43 with the TMA of I $3 \%$. The NPV was chosen as the forecast result. Table I below shows the cash flow.

\subsection{Analysis Made}

Initially the analysis was made to identify which variables have the most impact on NPV and to select among these the 5 most impacting variables in the cash flow result. Figure I below shows the initial developed graphic, on the abscissa axis is the NPV, and the green and orange colors respectively indicate NPV Positive and Negative.

From the initial tornado chart, the 5 main input variables that most impacted the NPV were chosen. That said, it was observed that the 5 main input variables that most impact the NPV are:

G8I: Selling price bottle of $20 \mathrm{~L}$;

G85: Sale price bottle of I 500 ml (pack w/ 06 units.);
GI 19: Costs preform PP I,500 ml;

G86: Selling price $500 \mathrm{ml}$ bottle (pack w/ 12 units); GI20: Costs with disposable labels.

The variables GI30, DI76, GI83, GI70, GI34, GI39, J56, G9I were discarded because they are unchangeable variables, for example the variable DI 76 which is the ICMS of $18 \%$. The other variables were discarded because they had a smaller impact on NPV.

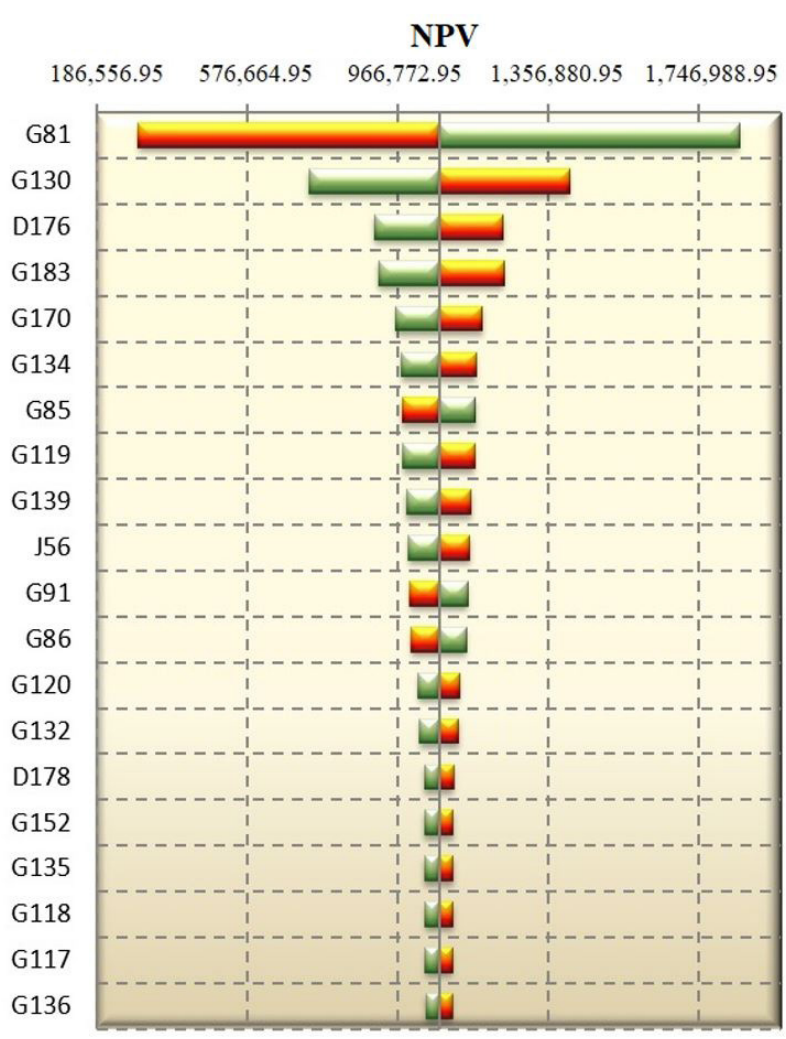

Figure I. Initial tornado chart.

Table I. Cash flow (ANM) [5]

\begin{tabular}{|c|c|c|c|c|c|c|}
\hline Year & 0 & $\mathbf{I}$ & 2 & 3 & $\ldots$ & 10 \\
\hline $\begin{array}{l}\text { Initial Investiment } \\
\text { (Capex) }\end{array}$ & $-2,053,000.00$ & & & & & \\
\hline Gross Revenue & & $2,736,976.62$ & $2,736,976.62$ & $2,736,976.62$ & $2,736,976.62$ & $2,736,976.62$ \\
\hline $\begin{array}{l}\text { Operational Cost } \\
\text { (Opex) }\end{array}$ & & I,587,251.09 & I,587,25।.09 & I,587,25I.09 & I,587,25I.09 & I,587,251.09 \\
\hline Taxes & & $459,538.37$ & $459,538.37$ & $459,538.37$ & $459,538.37$ & $459,538.37$ \\
\hline CFEM & & $22,774.38$ & $22,774.38$ & $22,774.38$ & $22,774.38$ & $22,774.38$ \\
\hline Net Revenue & & $667,412.78$ & $667,412.78$ & $667,4 \mid 2.78$ & $667,4 \mid 2.78$ & $667,412.78$ \\
\hline CSLL & & $60,067.15$ & $60,067.15$ & $60,067.15$ & $60,067.15$ & $60,067.15$ \\
\hline Taxable Profit & & $607,345.63$ & $607,345.63$ & $607,345.63$ & $607,345.63$ & $607,345.63$ \\
\hline Income Tax & & $91,101.84$ & $91,101.84$ & $91,101.84$ & $91,101.84$ & $91,101.84$ \\
\hline Net Profit & $-2,053,000.00$ & $576,310.93$ & $576,310.93$ & $576,310.93$ & $576,310.93$ & $576,310.93$ \\
\hline TMA & $13.00 \%$ & & & & & \\
\hline NPV & I,074,203.43 & & & & & \\
\hline TIR & $25.08 \%$ & & & & & \\
\hline Payback (years) & 3.56 & & & & & \\
\hline
\end{tabular}


Figure 2 below shows the sensitivity analysis made for the 5 variables that most impact the NPV, in the abscissa axis the NPV is found and the green and orange colors indicate, respectively, NPV Positive and Negative.

It is possible to observe that the present net value is more sensitive to the variation in the selling price of the $20 \mathrm{~L}$ bottle following, respectively, the changes in the sale price of the $1500 \mathrm{ml}$ bottle (pack w/ 06 units), PP preform costs $1.500 \mathrm{ml}$, the selling price of the $500 \mathrm{ml}$ bottle (pack with 12 units) and, finally, the cost of disposable labels. From the plotted graph of Figure 2 it is noticeable that the price of the $20 \mathrm{~L}$ bottle is the most impacting variable in the NPV and that a small price oscillation can significantly impact the present net value of the mineral water enterprise.

\subsection{Simulation of Monte Carlo}

There was generated a prediction chart of the NPV obtained through the simulation of Monte Carlo having as input variables the 5 most impacting. The forecast graphic is a probability histogram that shows the frequency of the values that occur in the total number of simulated attempts. The vertical bar shows the frequency at which a specific value of the NPV occurs in the total of attempts, while the cumulative frequency (soft line) shows the total probabilities of all values that occur in the forecast in $X$ and below it. Figure 3 below shows the prediction graphic of the NPV generated by the Monte Carlo simulation.

There were 100 thousand simulations performed and the normal probability distribution was used for the 5 most impacting variables. The average and standard deviation are the distribution parameters. The average NPV of the 100 thousand simulations was $R \$ 1,073,363.04$ and the standard deviation of $R \$ 794,957.59$. The NPV average was very close to the initial NPV of I, 074,203.43. The $95 \%$ confidence interval was between - $R \$ 483,875.00$ and 2,632,340.00. The forecast statistics, shown in Table 2 below, summarize the distribution of the forecast values found.

\subsection{Sensitivity Analysis}

The sensitivity graph identifies the impact on NPV when the 5 selected variables are simulated together. Figure 4 below shows the sensitivity graphic:

The explained percentage of variation calculates how much of the NPV variation can be explained by the variations in each of the 5 most impacting variables, in a dynamic simulation scenario [6]. These graphics show the sensitivity of the NPV forecast in relation to the 5 most impacted variables of the NPV. The variable that has the greatest impact on the model, as can be seen in Figure 4, on the sensitivity graphic is the price of the 20L bottle (G8I), followed respectively by the sale price of the $1500 \mathrm{ml}$ bottle (pack w/ 06-G85), costs preform PP I,500 $\mathrm{ml}$ (GI I 9), the selling price of the $500 \mathrm{ml}$ bottle (pack w/ I2 units - G86) and, finally, the cost of disposable labels ( $\mathrm{GI} 20)$.

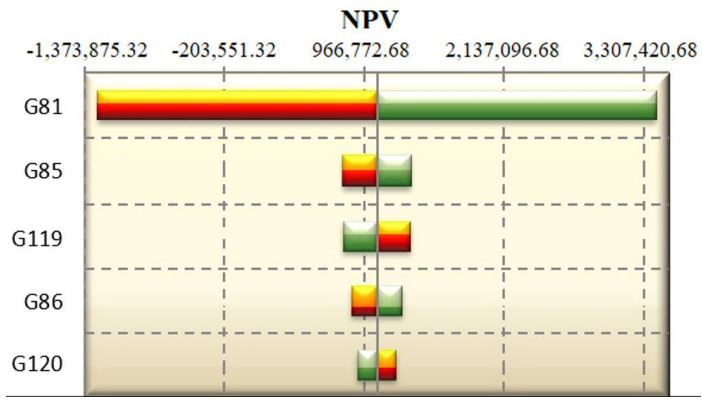

Figure 2. Graph made of the 05 most impacting variables of the NPV.

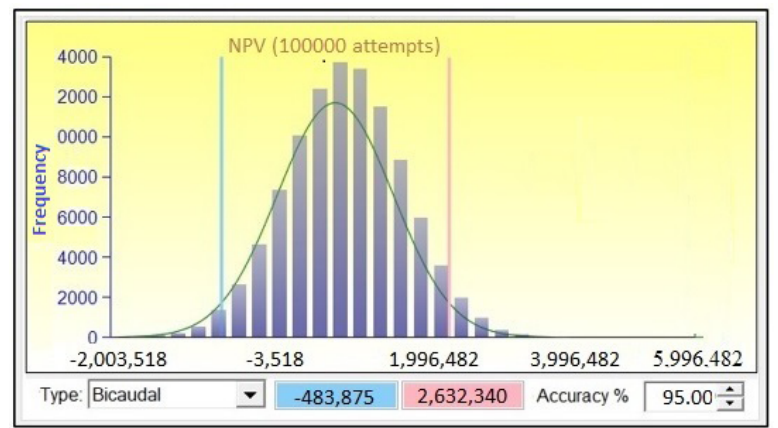

Figure 3. Graphic of probability's distribution of NPV resulting from the simulation of Monte Carlo.

\section{Percentage of explained variation}

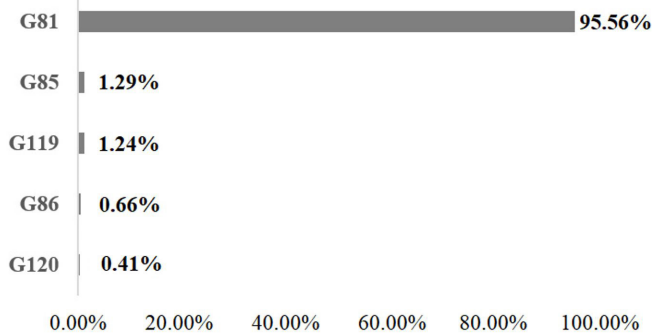

Figure 4. Sensitivity graphic of the 5 most impacting variables of the NPV.

Table 2. Statistics of the distribution of probability of the NPV resulting from the simulation of Monte Carlo

\begin{tabular}{lc}
\hline \multicolumn{2}{c}{ Statistics of the distribution of probability of the NPV } \\
\hline \multicolumn{1}{c}{ Statistics } & Result \\
\hline Number of attempts & 100.000 \\
Average & $\mathrm{I}, 073,363.0365$ \\
Median & $\mathrm{I}, 073,660.963 \mathrm{I}$ \\
Standard deviation & $794,957.5953$ \\
Variance & 0.7406 \\
Coefficient of variation & $63 \mathrm{I}, 957,578,381.5020$ \\
Maximum & $4,734,614.5796$ \\
Minimum & $-2,183,386.040 \mathrm{I}$ \\
Range & $6,918,000.6197$ \\
Obliquity & 0.0028 \\
Curtose & 0.0240 \\
$25 \%$ pertencile & $535,841.4188$ \\
$75 \%$ percentile & $\mathrm{I}, 610,576.5554$ \\
Percentage of error accuracy at & $0.4590 \%$ \\
$95 \%$ confidence & \\
\hline
\end{tabular}




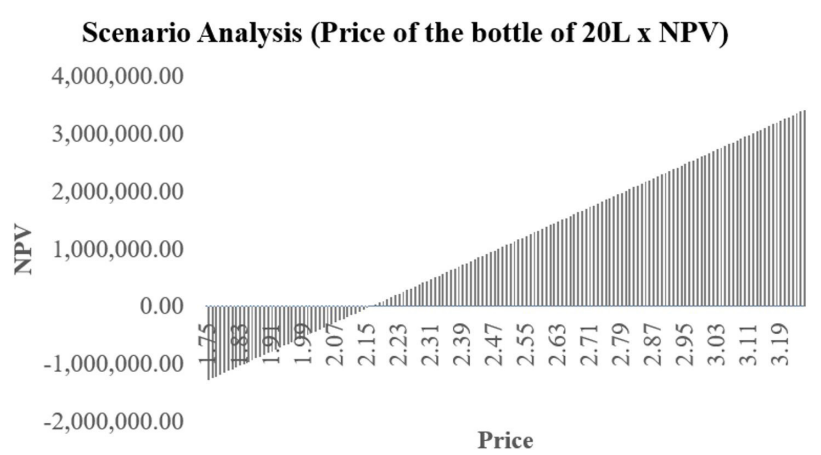

Figure 5. Scenario Analysis (Price of the bottle of 20L x NPV).

\subsection{Scenario Analysis}

The price variable of the 20L bottle (G8) was selected to be disturbed, since it was observed that this variable was the most impacting in the calculation of the cash flow studied and the net present value chosen to be the result of interest. The base value of the price of the $20 \mathrm{~L}$ bottle was defined as $R \$ 2.50$ and the initial and final values to be tested $\mathrm{R} \$ \mathrm{I} .75$ and $\mathrm{R} \$ 3.25$; respectively. The increase was $\mathrm{R} \$ 0.0$ I generating I 5 I simulations. The result was a scenario analysis chart as shown in Figure 5 below.

It is possible to observe that if there is only variation in the price of the $20 \mathrm{~L}$ bottle, the undertaking is only viable if the sale price is higher than $\mathrm{R} \$ 2$. I6. Thus, values below this make the venture economically unviable, while values above $\mathrm{R} \$ 2$. 16 make the venture economically viable.

\section{CONCLUSIONS}

Risk analysis using the Software risk simulator was important in assessing the viability of a mineral water enterprise. The objective of this article was to present the risk analysis generated by Software risk simulator in order to identify the viability of a mineral water enterprise. The realization of this study enabled the discovery of the most impacting variables in the cash flow for this mineral water enterprise.

The analysis made through the software risk simulator made it possible to understand the viability of a mineral water enterprise. Also, it was identified that the variable that most affects the profitability of the cash flow of this mineral water enterprise is the price of the $20 \mathrm{~L}$ bottle, followed respectively by the sale price of the $1500 \mathrm{ml}$ bottle (pack w/ 06 units), Costs preform PP I,500 ml, sale price of the bottle of $500 \mathrm{ml}$ (pack w/ I 2 units) and lastly the costs with disposable labels.

With the sensitivity analysis, it was observed that a small oscillation in price of the $20 \mathrm{~L}$ bottle can directly impact the viability of this mineral water undertaking. Therefore, it is important to perform the scenario analysis with the most impacting variable of the NPV, in the case of the price of the $20 \mathrm{~L}$ bottle. This analysis makes it possible to identify which minimum price should be applied to the market for profit.

Finally, all these analyses are essential to evaluate the risks of failure, the necessary investments and the economic viability of a mineral water enterprise, being the execution of all the steps carried out in this study fundamental for the planning and decision making.

\section{REFERENCES}

I Brandalise N, Cardoso R. Análise de risco em estudo de viabilidade econômico-financeira com o uso da simulação de Monte Carlo para o comércio de água mineral. In: Anais do XXX Encontro Nacional de Engenharia de Produção - ENEGEP; 2010; São Carlos, SP. Rio de Janeiro: ABEPRO; 2010.

2 Motta RR, Calôba GM. Análise de investimentos: tomada de decisão em projetos industriais. São Paulo: Editora Atlas; 2002. $392 \mathrm{p}$.

3 Monteiro CA, Santos LS, Werner L. Simulação de Monte Carlo em decisão de investimento para implantação de projeto hospitalar. In: Anais do XXXII Encontro Nacional de Engenharia de Produção - ENEGEP; 20I2; Bento Gonçalves, RS., 2012. Rio de Janeiro: ABEPRO.

4 Moore J, Weatherford LR. Tomada de decisão em administração com planilhas eletrônicas. 6. ed. Porto Alegre: Bookman Companhia Editora; 2006. 644 p.

5 Agência Nacional de Mineração. Plano de aproveitamento econômico. Brasília, DF: ANM; 2015.

6 Mun J. Risk simulator: manual do usuário. Califórnia: Real Options Valuation; 2012. 220 p.

Received: 24 Sept. 2018

Accepted: 25 Mar. 2019 